\title{
The role of SMEs finance in economic growth, and will their interactions lead to stimulating economic growth in Jordan?
}

\author{
Eyad Moufaq Alkousini \\ Department of Management Sciences, Al-Rashid International Private University, Damascus, Syria \\ E-mail: alkousinieyad@gmail.com \\ DOI: 10.29322/IJSRP.11.10.2021.p11858 \\ http://dx.doi.org/10.29322/IJSRP.11.10.2021.p11858
}

\begin{abstract}
This study aims to determine the impact of small and medium-sized finance on Jordan's economic growth. In addition to determine the effect of interaction between small and medium size finance on economic growth according to the theory of endogenous growth. For this purpose, time series analysis (Autoregressive Distributed Lag model) is used .

Due to the limited data available, quarterly data from small and medium-sized finance was used during this period (2016-2020). Results are shown that some of variables are stationary at the level and some stationary at the first difference. The results also show that there are long-term relationship between economic growth and explanatory variables. The estimate according to the first model showed that there is a significant negative effect of small finance, while the medium finance have positive insignificant impact on economic growth. In the second model, it agreed with the endogenous growth theory, that if small and medium finance interact with each other, the impact of these finance on economic growth will be positive and significant . The study finished with several recommendations, including the need to provide support to small projects to help them overcome the challenges they face, as well as removing obstacles to small and medium finance.

facilitating their access to sufficient and sustainable sources of funding, In addition to increasing government spending on research and development, to help these projects introduce innovative ideas that deepen the role of physical capital and increase its productivity. On the other hand, it is necessary to support the absorptive capacity (knowledge, skills and experience) of the workforce, and to encourage these companies to implement capital projects that would enhance education, training and skills acquisition for human capital
\end{abstract}

Keywords: small finance, medium finance, , Economic growth, endogenous growth theory

\section{Introduction}

Most of the developing countries strive for economic, social and political development in order to improve the well-being of their members. Small and medium enterprises are one of the most important factors in achieving economic growth, and they are a catalyst for economic development. Therefore, countries seeking to achieve sustainable economic growth must pay close attention to the SMEs sector and enhance its role in creating job opportunities, promoting local technology, diversifying production, building local entrepreneurship, and integrating with large industries (Aruwa \& Suleiman ،2004).

When the poor have access to financial services, they can earn more income, build assets, and protect themselves in the event of external shocks (Drechsel et al., 2012). microfinance enables clients to protect, diversify and increase income, as well as pooled assets, and reduce the impact of income and consumption shocks (Robinson,2002).

due to the massive population growth, and high unemployment rate, the government faces many challenges in providing sufficient job opportunities for the people. One effective way to solve the problem of unemployment is to provide people with small and 
medium finance and the necessary services to enable them to start or run a business of their choice (Osamwonyi and Obayagbona ,2012)

Economic growth cannot be achieved without poverty reduction by helping firms gain access to factors of production, especially credit. Entrepreneurship potential will be greatly enhanced by providing SMEs finance, promoting services that enable them to start a business, increase independence, employability and increase household income. Although the positive effects of SMEs but may be short-term due to the unsustainable nature of the programs and the continuing difficulties in obtaining adequate credit (Edafiaje ,2011)

Some researchers have attempted to identify problems such as weak infrastructure, weak capital development and weak institutional systems as some of the factors responsible for the slowdown in developing countries. New theories from academic research have shown that the economic miracle that third world countries need comes from the entrepreneurial factor, but these small and mediumsized companies face many problems such as lack of capital, labor, technological problem, marketing problem and many others (Olutuase, 2014)

For these reasons, the issue of SMEs is very important for economic decision makers in both developed and developing countries, including Jordan, but many problems hinder their development. The most obvious problem is financing channels, because financing plays an important role in meeting the needs of SMEs.

This research is based on the endogenous growth theory that affects economic growth by deepening the role of human capital, physical capital, and technological progress. All of this may help decision-makers in Jordan to design a policy to enhance SMEs role, or it may provide them with better and more realistic clarity on the current status of these finance. Therefore, this study seeks to answer the following important question: Do SMEs finance enhance economic growth in Jordan in addition to the answer to which sources of these financing are the most effective in promoting economic growth in addition to trying to reach What is obstructing the role of SMEs in engine economic growth? . In the second topic, the theoretical and applied dimensions of SMEs finance will be addressed, in the third topic the situation of SMEs finance in Jordan will be discussed. As for the study model, methodology and Econometrics analysis, it is covered by the fourth topic. Finally, the findings and recommendations will be addressed in the fifth topic. Due to limited data, previous studies did not study the relationship between SME financing and economic growth from a statistical perspective. This problem was solved by taking quarterly data (2016-2020), in addition this research will analyzing the impact of the interaction between SME financing elements on economic growth.

\section{Literature Review}

Enhancing entrepreneurship is key to raising the standard of living and promoting economic development. To reduce the high level of poverty, entrepreneurship must be embraced. The SMEs sector is widely seen as an important driver of economic growth and job development in both developing and developed countries and is the largest business sector in any global economy (Storey, 2016). Small and medium-sized enterprises create jobs faster than large companies, so governments around the world are increasingly promoting and supporting the development of small and medium-sized enterprises as part of an overall national development policy (Culkin \& Smith, 2000). These institutions contribute significantly to the diversification of economic activity and the achievement of social stability, and play an important role in the development of the private sector (Banking knowledge guide for small and medium enterprises,2009).

The following will be discussed about the importance of small and medium-sized companies

\section{1- Create job}

Small and medium-sized enterprises account for nearly $90 \%$ of global enterprises and employ 50\%-60\% of the global labor force, demonstrating their ability and efficiency to solve major problems faced by different economies.

Fast-growing entrepreneurship and small and medium-sized enterprises have made a significant contribution to job creation, and fast-growing companies survive better than non-growth companies.(Delmar et al., 2003).

Small and medium businesses are recognized as the solution to economic growth, modernization, job creation, income generation and scientific advancement in most advanced economies ( Rana \& Asad, 2008). The term 'Small and Medium Enterprises' is widely 
accepted in the business community because the sector is a tool for promoting employment growth, national development, poverty reduction and economic development. SMEs have more job opportunities than large corporations and multinational corporations (Kadiri,2012), and SMEs play a major role in poverty reduction, social growth and economic development. By establishing successful industrial enterprises, economic progress will be achieved and employment opportunities will be created for the public in the society in which the enterprise is located. Employment opportunities will increase the disposable income of the individual, resulting in greater demand for goods and services. These incomes will also improve living standards and reduce poverty. The average contribution of SMEs to employment growth in the EU was 1.1 million workers per year from 2002 to 2010 , equivalent to 0.9\% per year. SMEs create 900,000 jobs every year, accounting for $85 \%$ of the total number of new jobs (De Kok et al., 2011).

\section{2- Economic growth}

Entrepreneurship is one of the most powerful determinants of local economic strength. Small and medium enterprises have played a vital role in the economic growth of developing and underdeveloped countries. Small and medium businesses in particular are the engines of economic growth. By creating jobs, increasing tax collection, and contributing to GDP, the company represents nearly $90 \%$ of businesses in leading and developing economies. Although domestic production is weak, the strength of new and small firms is a major component of domestic competitiveness, which affects a country's economic performance. Small and mediumsized enterprises are among the largest economic boosters in developing countries. In 2001, the number of small and medium-sized enterprises in China reached 4.2 million, which represents $99 \%$ of the number of registered enterprises in China and is equivalent to $75 \%$ of the total value of industrial production (Chen, 2006). It helped create $79 \%$ of all new jobs across the state. The number of small and medium-sized companies in the world has increased, and the percentage in the Arab world varies from one country to another. In the Arab Gulf countries, small and medium industries constitute one of the most important sources of the industrial sector and are estimated to represent $85 \%$ of the total number of existing industrial establishments. A recent study conducted by the Gulf Investment Organization showed that small and medium-sized factories are equivalent to a percentage of the total factory size in the United Arab Emirates (94\%) and factories in Qatar, Oman, Bahrain (92\%) and Bahrain. (75\%) Saudi factory (78\%) Kuwait factory. Egypt and Syria make up about the same proportion of small and medium-sized companies, but their investment activities are different in nature. In Jordan, the service industry accounts for most of the number of SMEs, accounting for $70 \%$ of the number of Jordanian firms (Farajat .2009).

\section{3- Access to capital}

Small and medium enterprises are an economic field that contributes significantly to economic development and job creation. However, they also face great difficulties in obtaining the type of financing needed for growth (Pissarides, 1999). Finance plays an important role in entrepreneurship and the growth of small and medium-sized enterprises (SMEs). Therefore, favorable conditions provide the basis for survival, growth and competitiveness created by entrepreneurship (Lawal, Iyiola, and Adegbuyi, 2018). Since the business life cycle requires a wide range of currency requirements from inception and during the stages of growth and transformation in development, access to adequate and sustainable financing is essential for entrepreneurs and small and mediumsized businesses. In order to develop and maintain SMEs, entrepreneurs need to have access to various resources, such as financial capital, human capital, and physical capital, each of which plays an important role in the life cycle of a new enterprise Business (Fatoki, 2014), however, it poses a major challenge for SMEs to obtain financing, especially new, innovative and fast-growing businesses.Bank financing is very important to the operation of the economy because it is an important source of funding to support the development of SMEs. However, banks and financial institutions are hesitant to provide credit to the SMEs sector because early projects may have insufficient funding, lack of established track records, and insufficient capital (Fredriksson \& Moro, 2014). Therefore, they do not consider these companies to be viable companies. In other words, they do not see the return on investment of SMEs or whether it is possible to obtain a return on such investment.

\section{Constraints faced by SMEs:}


There is no doubt that SMEs play an important role in economic growth. However, on the other hand, the failure rate of SMEs is troubling both developing and developed countries. Several studies have shown that approximately $80-90 \%$ of SMEs will go bankrupt within 5-10 years (Ahmad, Abdul Rani, and Mohd Kassim, 2010; Kuratko and Hodgetts, 2004). Small and medium-sized business owners are faced with challenges related to the growing economy, various technologies, expertise, and resource shortages (Gummesson, 1994). Small and medium-sized enterprises are important for economic growth and development and job creation. Small and medium-sized enterprises need precise management to grow in the world economy. The success of entrepreneurship will show how to minimize poverty and how to improve the lives of people in the world's immature economies.

In order to compete internationally and achieve rapid growth, small and medium-sized businesses need management talents to overcome critical situations they may face and reach a more effective level (Al-Haddad et al., 2019). Research also shows that political uncertainty, lack of intellectual resources and infrastructure, fear of government authorities, and weak governments are another problem that small and medium-sized businesses face( Isa \& Shaari, 2011).another difficulties face These companies which is insufficient funds, Demanding guarantees in exchange for giving loan, The high interest rates on these loans are the highest (Sabha and Saymeh, 2014). Access to finance is more of a challenge for small businesses than large and medium businesses. The banking sector dominates the financial system, is less competitive and plays a limited role in financial intermediation, compared to other middle-income countries, and small businesses often turn to the informal sector or family and friends for the necessary financing (Nasser, S., El-Abed, 2013) .

\section{Applied studies}

The preceding discussion demonstrates, in theory, that the effect of SMEs on economic growth may be ambiguous. What about empirical evidence? In recent years, more and more literature has studied the economic impact of SMEs. Maow (2021) show that Poor management skills and certain government policies are the main obstacles faced by Somali SMEs. Inadequate import product policies, humanitarian assistance and unregulated competition have a negative impact on the development of small and mediumsized enterprises. Sabha and Saymeh (2014) also presented evidence from Jordan toAssessment of Small Enterprise Financing, Case of Jordan The researcher analyzed 345 questionnaires, and obtained a set of results through the analysis, which are summarized as follows: There is insufficient funding for these enterprises. The attitude of asking for a guarantee in exchange for a loan is relatively stubborn. The high interest rates on these loans are the most serious. Likewise, Akanbi, Akin and Sodiq (2016) Analysis of Small and Medium Scale Enterprises (SMEs) in Nigeria The result analysis shows that the direct relationship between Nigeria's SME financing and economic growth is not significant, which can be attributed to the inconsistency between SMEs and financing policies. Goedhuys and Sleuwaegen (2009) studied the growth performance of a large number of startups in 10 manufacturing sectors in 11 sub-Saharan African countries. The results showed that the growth of startups was affected by weak infrastructure, insecurity, and transportation, Constraints such as inconvenience, and financial constraints.

\section{Small and Medium Enterprises in Jordan}

The Jordanian economy is mainly regarded as an economy based on small and medium-sized enterprises. Small and medium-sized enterprises (SMEs) account for $98 \%$ of Jordanian enterprises, their employees account for approximately $60 \%$ of the labor force, and the total products account for approximately $50 \%$ of GDP. As Jordan develops into a highly free and open market economy, the SMEs sector is facing many challenges. The whole thing is rapidly moving and upgrading, which has caused prejudice and long-term effects on SMEs. Jordan began to implement an open market policy and deregulation in 2000. Nine years later, the SME sector was once again affected by the economic disaster. SMEs play an important role in improving employment in Jordan. In Jordan, there is no official definition that can clarify the definition of micro, small and medium enterprises for all public and private sector institutions. For the industrial sector, the Ministry of Industry and Trade (MIT)-through a cabinet decision in 2005-defines different parts of the industrial sector and enterprises, which are in line with its laws and regulations. The Central Bank of Jordan issued an official memorandum to the Banks of Jordan in 2011, in which companies are defined differently based on assets, turnover 
and number of employees. In addition to the formal sector, informal enterprises operate outside of the existing business registration and taxation system and the current zoning regulations, resulting in tax losses and weak supervision. In 2010, Jordan's informal sector was estimated to employ 487,861 workers, accounting for 44\% of the total employment in the Jordanian economy( Amawi, 2013). Table No. (1) shows the division of micro, small and medium companies according to the classification of the Central Bank and the Ministry of Industry and Trade

Table No. (1): division of micro, small and medium Enterprises

\begin{tabular}{|r|l|l|}
\hline & \multicolumn{2}{|c|}{ Number of Employees } \\
\hline & Jordan / Central Bank of Jordan & Jordan / Ministry of Industry and trade \\
\hline Micro & & $1-9$ \\
\hline Small & $5-20$ & $10-49$ \\
\hline Medium & $21-100$ & $50-249$ \\
\hline
\end{tabular}

Central Bank and the Ministry of Industry and Trade

From 2005 to 2012, the total number of registered companies in Jordan was 140,447. Small businesses with capital under JD 10,000 include 136,000 institutions (96.9\%). The classification the sectors that make up the Jordanian economy, they are as in Table No. (2) :

Table No. (2): classification the sectors that make up the Jordanian economy

\begin{tabular}{|l|l|}
\hline \multicolumn{1}{|c|}{ sectors } & \multicolumn{1}{c|}{ percentage } \\
\hline service and trade sectors & $71.5 \%$ \\
\hline Industrial & $18 \%$ \\
\hline construction & $3.6 \%$ \\
\hline Agriculture & $6.9 \%$ \\
\hline
\end{tabular}

Jordan Strategic Forum, 2013

It is noticed that most of the classification went towards the service and trade sectors sector, while the percentage directed to the industrial sector was weak, which limits the full use of these investments in projects that deepen the role of capital And therefore not the optimal use of these projects in the deepening of physical capital and human and therefore not to stimulate the growth in optimal way according to endougenous growth theory.

Partnerships/Limited Partnerships are still the highest, with 38,319 companies 59.9\%.

The total number of employees in the private sector in 2010 was 671,575 . Micro and small enterprises accounted for $58.4 \%$ of Jordan's total employment, for a total of 392,250. if we Add medium-sized enterprises, this proportion will exceed 66\%. (Jordan Strategic Forum, 2013). According to the 2014 Doing Business Report, Jordan's ranking has declined on multiple levels including entrepreneurship, operations, and existing companies. This shows that despite the fragmented efforts to modernize the business environment, international organizations and the Jordanian business community always list the same challenges faced by companies. It is also worth mentioning that in the 2013-2014 Global Competitiveness Report, Jordan's ranking among 148 economies dropped to 68. As shown in the figure (1), the private sector has identified labor regulations, tax rates, and financing channels as challenges facing companies and many of other challenges, Figure No (1): challenges facing Small and Medium Enterprises in Jordan 
Figure No (1): challenges facing Small and Medium Enterprises in Jordan

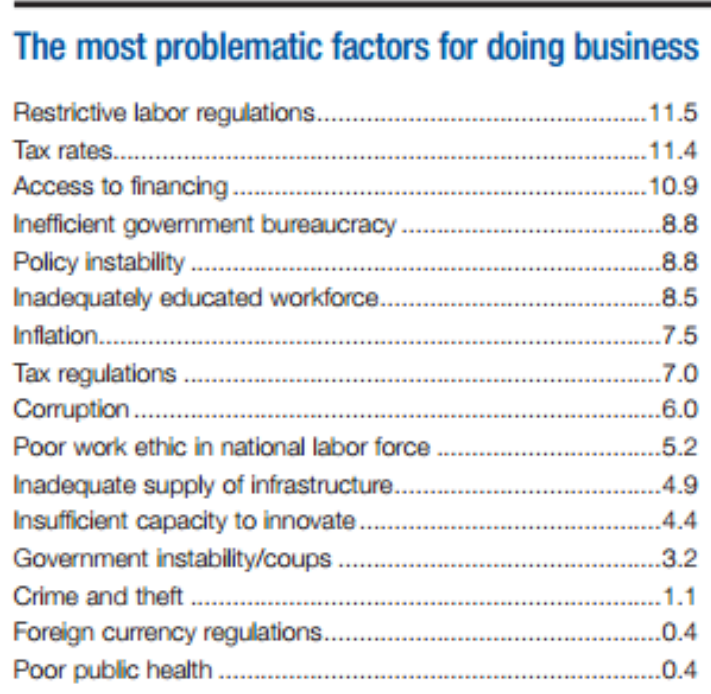

the Global Competitiveness Report 2013-2014, World Economic Forum

\section{Small and medium business interaction}

A coordinated policy approach is needed to support the expansion of SMEs and start-ups. The institutional and regulatory environment, as well as the relaxation of policies for SMEs to enter the market and strategic resources for scaling up, including growth capital, workers and management skills, as well as knowledge and technology, are all critical. Strengthening partnerships between SMEs, large companies, investors, universities and research centers, including at the local level, can stimulate the growth of SMEs (SME Ministerial Conference,2018).

How can SMEs systematically identify specific constraints and performance gaps that hinder their competitiveness? Where can they go for help? One way is to establish close relationships with other members of the supply chain, hoping to benefit from their experience. Conferences, trade shows, consultants, trade journals and industry groups may be helpful (OCED,2004). To help SMEs reach their potential, large companies must participate. Large companies spend billions of dollars each year seeking products and services from other companies, such as landscaping, cleaning services, logistics, software development, food services, and office supplies. A study conducted by the Center for an Urban Future.of nearly 200 small businesses in the United States showed that seven out of ten small businesses have increased their revenue and scale within two years of becoming the base of business suppliers (Center of an urban future, 2014).

When small companies interact with large companies, these SMEs will make changes to improve their organizational structure, management practices, and operations. These changes have caused small companies to upgrade their technology, improve their efficiency, and most importantly, become financially stable. As a result, income has become larger and more stable, making it possible for these companies to add new jobs. Owning a large company as a client also opens the door to easier access to credit and other business opportunities. The biggest benefit is the overflow of new knowledge, innovation and business models. When some small businesses improve their systems or business models, other small businesses can learn from it and increase competitiveness to maintain competitiveness, thereby improving the quality of the entire SMEs sector (OCED,2004). To sum up, this study will test the second model based on the interaction of SMEs financing to find the importance of this interaction for stimulating economic growth, and compare the results with the first model. This interaction is a simulation of Borenszteina et al. (1998), which tested the interaction between foreign direct investment and human capital. 


\section{Methodology}

The study is based on the theory of endogenous growth, in a simulation of the Romer model (1990), and by relying on Borenszteina et al (1998) and Makki (2004) who relied on the endogenous growth model, Borenszteina et al (1998) estimated the impact of foreign direct investment On the growth of five developing countries for the period (1978-1998) and reached a positive role for foreign direct investment on economic growth and overcoming the role of domestic investment. He attributed this to the ability of foreign investment to transfer new technology and deepen the role of capital. He also found that the interaction of foreign investment and human capital (by adding a variable representing the result of multiply foreign investment variable with human capital variable) positively affects growth. As for the Makki study (2004), the trade variable (exports + imports) was added to Borenszteina et al (1998) to study the effect of foreign investment and the external sector on growth in 66 developing countries for the period (19792004). There are other studies that used a endogenous growth model to determine the effect of variables believed to play a role in growth. Elmawazini et al (2015) dealt with the impact of the banking sector, and Haiss and Sumegi (2008) dealt with the impact of the insurance sector. The current study deals with the impact of SMEs finance in economic growth, as these components contribute to raising productive capacity by deepening the role of capital and raising the absorptive capacity (improving human capital and disseminating technology). Accordingly, the study form can be formulated as follows

$$
G D P=f(S F, \mathrm{MF}, I N T, I N F)
$$

Where (GDP): Gross Domestic product, (SF): Small finance, (MF): Med finance, (INT): intrest rate, (INF): inflation rate

\section{Analysis Results}

The economic analysis of the study subject is based on time series data, and this analysis requires the estimation of the Econometrics relationships between the study variables. Accordingly, preliminary statistical tests must first be conducted to determine the appropriate method for estimating these relationships, and this includes testing the unit root for data for each time series included in the estimation of the Econometrics relationship. Table No. (3) refers to the results of the unit root test, as the results showed that ( GDP, SF) stationary on level I(0), (MF,INT,INF) not stationary in levels but stationary at the first degree (I (1)).

Table No. 3: Phillip-Perron Test Results

\begin{tabular}{|c|c|c|c|c|c|}
\hline \multirow{2}{*}{ Variables } & \multicolumn{2}{|c|}{ Level } & \multicolumn{2}{|c|}{ 1st differ. } & \multirow{2}{*}{ Integrated } \\
\hline & Intercept & intercept and trend & Intercept & intercept and trend & \\
\hline GDP & $\begin{array}{c}-3.40 \\
(0.024 *)\end{array}$ & $\begin{array}{c}5.83 \\
\left(0.0008^{*}\right)\end{array}$ & $\begin{array}{c}-6.08 \\
(0.0001)\end{array}$ & $\begin{array}{c}-5.619 \\
(0.0003)\end{array}$ & $\mathrm{I}(0)$ \\
\hline $\mathrm{MF}$ & $\begin{array}{l}-1.14 \\
(0.68) \\
\end{array}$ & $\begin{array}{l}-2.57 \\
(0.23)\end{array}$ & $\begin{array}{c}-7.77 \\
(0.0000 *)\end{array}$ & $\begin{array}{c}-7.27 \\
(0.0001 *)\end{array}$ & $\mathrm{I}(1)$ \\
\hline $\mathrm{SF}$ & $\begin{array}{l}-0 . .62 \\
(0.84)\end{array}$ & $\begin{array}{c}-3.67 \\
(0.0498 *)\end{array}$ & $\begin{array}{c}-10.07 \\
(0.0000)\end{array}$ & $\begin{array}{c}-8.87 \\
(0.0000)\end{array}$ & $\mathrm{I}(0)$ \\
\hline INT & $\begin{array}{l}-1.51 \\
(0.50)\end{array}$ & $\begin{array}{c}-0.98 \\
(0.92)\end{array}$ & $\begin{array}{c}-3.59 \\
\left(0.016^{*}\right)\end{array}$ & $\begin{array}{c}-5.45 \\
(0.0019 *)\end{array}$ & $\mathrm{I}(1)$ \\
\hline INF & $\begin{array}{l}-2.01 \\
(0.27)\end{array}$ & $\begin{array}{l}-0.79 \\
(0.95)\end{array}$ & $\begin{array}{c}-3.45 \\
(0.0222 *)\end{array}$ & $\begin{array}{c}-4.24 \\
\left(0.018^{*}\right)\end{array}$ & $\mathrm{I}(1)$ \\
\hline
\end{tabular}

\section{Results of a Autoregressive Distributed Lag (ARDL) estimation:}

Since we have some variables Stationary on the level and some variables in the first difference are Stationary, we used the ARDL model. For the co-integration test, we use the Bounds test. The results of the co-integration test are summarized in Table 4 below. 
From Table 4, use the ARDL bound test co-integration program, and the co-integration relationship between them. This can be seen from the value of the F statistic, which is greater than all critical value Bounds. Based on this result, we cannot accept the null hypothesis that there is no cointegration between variables. Therefore, there is a long-term relationship between the specific dependent variable and the selected independent variable. Therefore, the ARDL model can be estimated for the relationship.

One of the advantages of the ARDL test is that it can be applied to small samples and give valid results. We can determine the short-term and long-term relationship between the independent variables and the dependent variable It is also possible to specify different time lags for the variables, which is not possible in the cointegration test (Pardhan,2013).

Table No. 4: ARDL Bounds Test Results

\begin{tabular}{|c|c|c|}
\hline $\mathrm{k}$ & Value & Test Statistic \\
\hline 4 & 30.78 & F-statistic \\
\hline \multicolumn{3}{|c|}{ Critical Value Bounds } \\
\hline I1 Bound & I0 Bound & Significance \\
\hline 3.01 & 1.9 & $5 \%$ \\
\hline 3.48 & 2.26 & $2.5 \%$ \\
\hline 3.9 & 2.62 & $1 \%$ \\
\hline 4.44 & 3.07 & $5 \%$ \\
\hline
\end{tabular}

\section{Analysis of Regression Results}

Table No. (5) show the effect of the explanatory variables on economic growth in short term. It is noted that small finance have a negative impact and significance at the 5 percent level. medium finance have positive impact but insignificance at the 5 percent level. The results showed that the error correction coefficient (speed of adjustment) is negative and statistically significant, which indicates that economic growth in Jordan is affected by the explanatory variables used in the models in the long run.

Table No (5) : ARDL Cointegrating And short Run Form

\begin{tabular}{|c|c|c|c|c|}
\hline Variable & Coefficient & Std. Error & t-Statistic & Prob. \\
\hline D(GDP2(-1)) & 0.838416 & 0.101598 & 8.252314 & 0.0000 \\
\hline D(MED) & 0.354723 & 0.348515 & 1.017811 & 0.3353 \\
\hline D(SMALL) & -2.397919 & 0.634532 & -3.779032 & 0.0044 \\
\hline D(CONSUMER_PRICE_INDEX) & -42.095506 & 48.763853 & -0.863252 & 0.4104 \\
\hline D(INTREST_RATE) & 16889.550657 & 11022.745715 & 1.532245 & 0.1598 \\
\hline CointEq(-1) & -1.648429 & 0.155030 & -10.6329 & 0.0000 \\
\hline
\end{tabular}

The Long Run Analysis:

Table No. (6) show The results of the long run model. It is noted that small finance have a negative impact and significance at the 5 percent level. medium finance have positive impact but insignificance at the 5 percent level. The reason may be due to the difficult faces the SMEs in Jordan (restriactive labor regulations, tax rates, and access to finance, policy instability, inaduqate insufficient capacity of inovation, inadequate educated work force insufficient infrastrcutre channels) (Global Competitiveness Report,2014) and maybe can attribute to small percentage of industrial sector $18 \%$ from the all sectors that make up the Jordanian economy. which makes benefit at Minimum of these projects. trade and service sector do not deepeinig the role of physical or human capital or spread technology according to endogenous growth theory.

Table No (6) : ARDL Cointegrating Long Run Results 


\begin{tabular}{|c|c|c|c|c|}
\hline Variable & Coefficient & Std. Error & t-Statistic & Prob. \\
\hline MED & 0.215189 & 0.217760 & 0.988189 & 0.3489 \\
\hline SMALL & -1.001006 & 0.328489 & -3.047308 & 0.0139 \\
\hline CONSUMER_PRICE_INDEX & 68.521648 & 7.005135 & 9.781632 & 0.0000 \\
\hline INTREST_RATE & 357.101299 & 5325.610316 & 0.067054 & 0.9480 \\
\hline
\end{tabular}

\section{Diagnostic tests}

Diagnostic tests are carried out in order to ensure the quality of the model used for analysis and that it is completely free from Econometrics problems. Table No. (7) shows the results of these tests. It is noted that the Normality of Residuals Test has a probability value of 0.77 , which means that the null hypothesis cannot be rejected that states that the residuals of the model are normally distributed. As for the Serial Correlation test between the random errors, the results of the estimation showed that the probability value of the test is 0.58 , indicating that there is no serial correlation between the errors. As for the heteroskedasticity test, the probability value of the test in the model was (0.91) and it is not statistically significant, and therefore it can be concluded that there is no difference in the variance of random errors

Table No. (7): Diagnostic tests

\begin{tabular}{|c|c|c|c|c|c|}
\hline \multicolumn{2}{|c|}{ Normality Test } & \multicolumn{2}{c|}{ Heteroskedasticity Test } & \multicolumn{2}{c|}{ Serial Correlation Test } \\
\hline Jarque-bera & Prob. & F-statistic & Prob. & F-statistic & Prob. \\
\hline 0.51 & 0.77 & 0.38 & 0.91 & 0.57 & 0.58 \\
\hline
\end{tabular}

\section{The second model:}

To find out the effectiveness of the interaction of small finance and medium finance on economic growth, we will replace the small and medium finance variables with a variable multiplying of the small finance variable with medium finance so that this last variable represents the outcome of the interaction of both variables

\section{Results of a Autoregressive Distributed Lag (ARDL) estimation:}

Since we have some variables Stationary on the level and some variables in the first difference are Stationary, we used the ARDL model. For the co-integration test, we use the Bounds test. The results of the co-integration test are summarized in Table 8 below. From Table 8, use the ARDL bound test co-integration program, and the co-integration relationship between them. This can be seen from the value of the F statistic, which is greater than all critical value Bounds. Based on this result, we cannot accept the null hypothesis that there is no cointegration between variables. Therefore, there is a long-term relationship between the specific dependent variable and the selected independent variable. Therefore, the ARDL model can be estimated for the relationship.

Table No. 8: ARDL Bounds Test Results

\begin{tabular}{|c|c|c|}
\hline $\mathrm{k}$ & Value & Test Statistic \\
\hline 3 & 15.46 & F-statistic \\
\hline \multicolumn{2}{|c|}{ Critical Value Bounds } \\
\hline I1 Bound & I0 Bound & Significance \\
\hline 3.77 & 2.72 & $5 \%$ \\
\hline 4.35 & 3.23 & $2.5 \%$ \\
\hline 4.89 & 3.69 & $1 \%$ \\
\hline 5.61 & 4.29 & $5 \%$ \\
\hline
\end{tabular}




\section{Analysis of Regression Results}

Table No. (9) show the effect of the explanatory variables on economic growth in short term. It is noted that small and medium finance integration have a negative impact and significance at the 5 percent level. The results showed that the error correction coefficient (speed of adjustment) is negative and statistically significant, which indicates that economic growth in Jordan is affected by the explanatory variables used in the models in the long run.

Table No (9) : ARDL Cointegrating And short Run Form

\begin{tabular}{|c|c|c|c|c|}
\hline Variable & Coefficient & Std. Error & t-Statistic & Prob. \\
\hline D(GDP2(-1)) & 1.402379 & 0.219633 & 6.385115 & 0.0014 \\
\hline D(GDP2(-2)) & 0.486825 & 0.198318 & 2.454772 & 0.0576 \\
\hline D(MEDSMALL) & -0.000503 & 0.000407 & -1.235609 & 0.2715 \\
\hline D(MEDSMALL(-1)) & -0.000140 & 0.000493 & -0.284206 & 0.7876 \\
\hline D(MEDSMALL(-2)) & -0.001707 & 0.000429 & -3.980401 & 0.0105 \\
\hline D(CONSUMER_PRICE_INDEX) & -31.184503 & 37.441750 & -0.832880 & 0.4429 \\
\hline D(INTREST_RATE) & 5404.069759 & 10465.780299 & 0.516356 & 0.6276 \\
\hline CointEq(-1) & -3.088765 & 0.421098 & -7.335025 & 0.0007 \\
\hline
\end{tabular}

\section{The Long Run Analysis:}

Table No. (10) shows The results of the long-run model. It is noted that small and medium finance integration has a positive impact and significance at the 5 percent level. The reason that may be due to having a positive impact of small and medium finance on economic growth is to establish close relationships between small and medium finance with the supply chain of these firms, hoping to benefit from their experience(OCED,2004).

When these companies interact with each other, SMEs will make changes to improve their organizational structure, management practices, and operations. These changes have caused small companies to upgrade their technology, improve their efficiency, and most importantly, become financially stable. As a result, income has become larger and more stable, making it possible for these companies to add new jobs. Owning a large company as a client also opens the door to easier access to credit and other business opportunities. The biggest benefit is the overflow of new knowledge, innovation. all of these improve capital deepening and improve the human capital experience and make them have new knowledge, so that improve the role of a medium and small firm in economic growth due to the endogenous growth theory.

Table No (10) : ARDL Cointegrating Long Run Results

\begin{tabular}{|c|c|c|c|c|}
\hline Variable & Coefficient & Std. Error & t-Statistic & Prob. \\
\hline MEDSMALL & 0.000388 & 0.000106 & 3.675048 & 0.0144 \\
\hline CONSUMER_PRICE_INDEX & 17.335878 & 7.833259 & 2.213112 & 0.0778 \\
\hline INTREST_RATE & -1161.760306 & 3001.906052 & -0.387008 & 0.7147 \\
\hline
\end{tabular}

\section{Diagnostic tests}

Diagnostic tests are carried out in order to ensure the quality of the model used for analysis and that it is completely free from Econometrics problems. Table No. (11) shows the results of these tests. It is noted that the Normality of Residuals Test has a probability value of 0.48 , which means that the null hypothesis cannot be rejected that states that the residuals of the model are normally distributed. As for the Serial Correlation test between the random errors, the results of the estimation showed that the probability value of the test is 0.14 , indicating that there is no serial correlation between the errors. As for the heteroskedasticity 
test, the probability value of the test in the model was (0.67) and it is not statistically significant, and therefore it can be concluded that there is no difference in the variance of random errors.

Table No. (11): Diagnostic tests

\begin{tabular}{|c|c|c|c|c|c|}
\hline \multicolumn{2}{|c|}{ Normality Test } & \multicolumn{2}{c|}{ Heteroskedasticity Test } & \multicolumn{2}{c|}{ Serial Correlation Test } \\
\hline Jarque-bera & Prob. & F-statistic & Prob. & F-statistic & Prob. \\
\hline 1.45 & 0.48 & 0.75 & 0.67 & 3.18 & 0.14 \\
\hline
\end{tabular}

\section{7- Conclusion and Recommendations:}

There is a lot of literature on the challenges faced by small businesses and start-ups in accessing finance and suggested solutions for dealing with them. However, many of these recommendations turned out to be difficult to implement due to the lack of sufficient public funds that can be allocated to support small businesses and the low appetite of commercial banks to provide credit lines to such companies due to the level of risk associated with them compared to larger enterprises and businesses that can provide traditional collateral such as real estate and cash deposits. The results of the research also showed the negative significant impact of small finance on economic growth in the short and long term, and positive, insignificant impact of medium finance. in the second model, and when the interaction between small and medium finance was introduced, the impact became positive and signifiacnt, which indicates the importance of this interaction between the two SMEs finance.

When these companies interact with each other, SMEs will make changes to improve their organizational structure, management practices, and operations. These changes have prompted small companies to upgrade their technology, improve efficiency, and most importantly, become financially stable. As a result, income has become larger and more stable, making it possible for these companies to add new jobs. Owning a large company as a client also opens the door to easier access to credit and other business opportunities. The biggest benefit is the overflow of new knowledge and innovation. These have promoted the deepening of capital, improved the experience of human capital, and enabled them to acquire new knowledge, thereby enhancing the role of endogenous growth theory in the economic growth of small and medium-sized enterprises.

\section{References}

Amawi, M.(2013) Challenges of Starting a Small Business in Jordan. Jordan strategy forum

Ahmad, S. Z., Abdul Rani, N. S., \& Mohd Kassim, S. K. (2010). Business challenges and strategies for development of small-and medium-sized enterprises (SMEs) in Malaysia. International Journal of Business Competition and Growth, 1(2), 177-197.

Akanbi, B. Akin,O. Sodiq, A. (2016). "Analysis of Small and Medium Scale Enterprises (SMEs) Financing and Economic Growth: Which Way for Nigeria, European Journal of Business and Management. Vol.8, No.16,

Al Farajat, Issa, (2009), "The reality of small and medium enterprises in the Arab world," Finance and Economic Blog, Internet, September 7, 2009

Al-Haddad, L., Sial, M. S., Ali, I., Alam, R., Khuong, N. V., \& Thuy, T. H. (2019). The role of small and medium enterprises (SMEs) in employment generation and economic growth: a study of marble industry in emerging economy. Int J Financial Res, 10(6).

Aruwa, A.Suleiman, A. (2004). Financing options for small and medium scale enterprises in Nigeria. Small, 50, 99. 
Bein, M and Ebosetale, I. (2017). THE IMPACT OF MICROFINANCE INSTITUTION IN ECONOMIC

GROWTH OF A COUNTRY: NIGERIA IN FOCUS. International Journal of Development and Management Review (INJODEMAR) Vol.12 No. 1

Bhutta, M. K. S., Rana, A. I., \& Asad, U. (2008). Owner characteristics and health of SMEs in Pakistan. Journal of Small Business and Enterprise Development

Borenszteina, E. De Gregoriob, J. Lee, J-W. (1998). "How does foreign direct investment affect economic growth?". Journal of International Economics. 45: 115-135.

Center of an urban future. (2014). SMALL BUSINESS SUCCESS

Chen, J. (2006). Development of Chinese samall and medium sized enterprises. Journal of Small Business and Enterprise Development, Vol. 13 No. 2, pp. 140-147.

Culkin, N., \& Smith, D. (2000). An emotional business: a guide to understanding the Motivation of small business decision takers. Qualitative Market Research: An International Journal.

De Kok, J., Vroonhof, P., Verhoeven, W., Timmermans, N., Kwaak, T., Snijders, J., \& Westhof, F. (2011). Do SMEs create more and better jobs. Report prepared by EIM for the European Commission DG Enterprise and industry, Brussels, European Commission

Delmar, F., Davidsson, P., Gartner, W.B (2003). "Arriving at the high-growth firm." Journal of Business Venturing 18: $189-216$

Drechsel, G. et al.(2013). Nonsense-mediated decay of alternative precursor mRNA splicing variants is a major determinant of the Arabidopsis steady state transcriptome.Plant Cell. 2013; 25: 3726-3742.

Edafiaje, A. L. (2011). "IMPACT ASSESSMENT OF THE ROLE OF MICROFINANCE BANKS IN FINANCING SMALL SCALE ENTERPRISES IN DELTA STATE, NIGERIA". International Journal of Economic Development Research and Investment Vol 2 No. 3.

Fredriksson, A., \& Moro, A. (2014). Bank-SMEs relationships and banks' risk-adjusted profitability. Journal of Banking \& Finance, 41, 67-77.

Gummesson, E. (1994). Making relationship marketing operational. International Journal of service industry management.

Kadiri, I. B. (2012). Small and medium scale enterprises and employment generation in Nigeria: The role of finance. Kuwait Chapter of Arabian Journal of Business and Management Review, 33(845), 1-15.

Khalique, M., Isa, A. H. B. M., \& Nassir Shaari, J. A. (2011). Challenges for Pakistani SMEs in a knowledgebased economy. Indus Journal of Management \& Social Sciences, 5(2).

Lawal, F. A., Iyiola, O. O., \& Adegbuyi, O. A. (2018). Exploring alternative financing for entrepreneurship development in Nigeria: Surmounting challenges. Journal of Entrepreneurship Education, 21(1), 1-11.

Makki, S. (2004)."Impact of Foreign Direct Investment and Trade on Economic Growth", American Journal of Agricultural Economics vol. 86, issue 3, 795-801

Nasr,S and El Abd,Y,2013, DEVELOPING MICRO, SMALL \& MEDIUM ENTERPRISES IN JORDAN: THE ROUTE TO SHARED PROSPERITY, MENA Knowledge and Learning, World Bank

OECD. (2004). conference of ministers responsible for small and medium sized enterprises. Promoting entrepreneurship and innovative SMEs in global economy.

Olutuase, S. O. (2014). Entrepreneurship Model for Sustainable Economic Development in Developing Countries Osamwonyi, I.O. \& Obayagbona, J. (2012). The Role of Microfinance Banking in the Development of the Nigerian Economy. Finance \& Banking Review, 6(1\&2), Jan/July, 46-66 

ISSN 2250-3153

Pissarides, F. (1999). Is lack of funds the main obstacle to growth? EBRD's experience with small-and mediumsized businesses in Central and Eastern Europe. Journal of Business Venturing, 14(5-6), 519-539.

Robinson, S, M. (2002). The Microfinance Revolution: Sustainable Finance for the Poor. USA: World Bank Publication. 